\title{
URGENSI TASAWUF DALAM MEMBANGKITKAN KESADARAN SPIRITUAL BAGI MASYARAKAT MODERN
}

\section{THE URGENCY OF SUFISM IN RAISING SPIRITUAL CONSCIOUSNESS FOR MODERN SOCIETY}

\author{
Aminudin ${ }^{1}$ \\ ${ }^{1}$ IAIN Sultan Amai Gorontalo, Indonesian, Emai:aminudin@iaingorontalo.ac.id
}

\begin{abstract}
This article will examine the urgency of Sufism in awakening the spiritual awareness of modern society. Sufism for modern society is very important, because society has been trapped in a rational mindset and has abandoned the inner dimension, giving birth to a materialist and hedonistic lifestyle, meaning that people only think about worldly life without paying attention to the life of the ukhrawi. Therefore spiritual awareness is needed to overcome these problems. Why does Sufism emphasize spirituality in the various aspects? This is because the masters of Sufism, whom we call Sufis, believe in the superiority of spirit over the body; believe in the spiritual world rather than the material world. Sufism is also often identified with ihsan, which is the highest stage a Muslim must take to reach his God. And as for the characteristics of Sufism is an increase in awareness of the importance of morality/ethics.
\end{abstract}

Keyword: Sufism, Spiritual Awareness, Modern Society.

\begin{abstract}
Abstrak: Artikel ini akan mengkaji tentang urgensi tasawuf dalam membangkitkan kesadaran spiritual masyarakat modern. Tasawuf bagi masyarakat modern sangat penting, karena masyarakat telah terperangkap dalam pola pikir rasional dan mencampakkan dimensi batin, hingga melahirkan gaya hidup yang materialis dan hedonis, dalam arti masyarakat hanya berpikir kehidupan duniawi semata tanpa menghiraukan kehidupan ukhrawi. Oleh sebab itu diperlukan kesadaran spiritual untuk mengatasi problema tersebut. Mengapa tasawuf lebih menekankan aspek spritualitas dalam berbagai aspeknya? Ini karena para ahli tasawuf, yang kita sebut sufi, memercayai keutamaan spirit ketimbang jasad, mempercayai dunia spiritual ketimbang dunia material. Tasawuf juga sering di identikkan dengan ihsan, yang merupakan sebuah tahapan tertinggi yang harus ditempuh oleh seorang muslim untuk menuju Tuhannya. Adapun yang menjadi karakteristik tasawuf ialah peningkatan kesadaran akan pentingnya moralitas/etika.
\end{abstract}

Kata kunci: Tasawuf, Kesadaran Spiritual, Masyarakat Modern 


\section{PENDAHULUAN}

Islam adalah agama yang sejak awal diturunkannya diterima dan diamalkan oleh masyarakat urban, atau masyarakat perkotaan di Makkah dan Madinah. Yakni diterima suatu lapisan masyarakat yang mampu berpikir rasional dan logis, mampu membedakan dan menarik garis pemisah yang tegas antara yang Islam dan bukan Islam. Oleh karena itu, walaupun kini Islam telah banyak mendapat pegaruh berbagai macam peradaban tradisi jahiliyah, namun ilmu pengetahuan modern menawarkan kemampuan untuk menggunakan analisis kritik kesejarahan bagi umat yang rindu pada jiwa Islam yang murni seperti diamalkan Nabi dan sahabat-sahabat beliau.

Telah banyak diakui bahwa manusia modern telah mengalami apa yang disebut Nasr sebagai krisis spiritual. Krisis spritual ini terjadi pengaruh sekularisasi yang telah cukup lama menerpa jiwa-jiwa manusia modern. Kecenderungan manusia untuk mencari kembali nilai-nilai Ketuhanan merupakan bukti manusia pada dasarnya sebagai mahkluk rohani dan makhluk jasmani. Sebagai mahkluk jasmani, manusia butuh sesuatu ang bersifat materi, sedangkan manusia sebagai makhluk rohani butuh sesuatu yang bersifat immateri. Hal ini sesuai dengan orieantasi ajaran dalam tasawuf yang lebih menekankan pada aspek rohani sesuai dengan fitrah manusia yang pada dasarnya cenderung bertasawuf. ${ }^{1}$

Oleh karena itu, adanya nilai-nilai moral sangat dibutuhkan dalam upaya memberikan bentuk dan arah terhadap pola tingkah laku manusia yang berkaitan dengan seluruh jaringan kehidupannya, baik individu maupun social. Tanpa adanya sikap akhlak pada diri manusia akan menyebabkan ketidakseimbangan dalam mengembangkan kepribadiannya. Ia hanya unggul dalam ilmu pengetahuan saja tetapi sangat terasing dengan nilai-nilai kemanusiaan yang ada pada dirinya dan pada akhirnya keunggulan yang dia raih tidak memberikan ketenteraman pada diri manusia serta masyarakat pada umumnya.

1 Asmaran, Pengantar Studi Tasawuf, (Jakarta: PT. Raja Grafindo Persada, 2012), hlm.17. 
Islam di Indonesia telah berkembang sedemikian rupa sehingga kini tampak sangat formalis dalam beragama, seolah tidak ada lagi segi religiusitasnya. Bentuk-bentuk keshalihan formal dan keshalihan individual begitu menonjol. Keberagamaan sangat semarak, rumah ibadah (masjid, mushola, madrasah, dan sebagainya) berkembang pesat di mana-mana, jumlah orang menunaikan ibadah haji meningkat, tetapi dari segi substansial, sebagai bangsa, keberagamaan rupanya belum mencerminkan nilai-nilai hakiki Islam lebih-lebih merefleksikan esensi ihsan. ${ }^{2}$ Apa yang disebut egalitarianisme, keadilan, kesadaran humanitarian, hormat kepada hukum dan hak-hak asasi manusia, kesadaran lingkungan, kebersihan, penghargaan terhadap orang yang lemah, sikap inklusif dan pluralis dan begitu seterusnya, yang jelas merupakan nilai-nilai dasar agama, ternyata nilai religiusitasnya nyaris tidak tercermin dalam kehidupan masyarakat. Kiranya, sangat tepat jika saatnya penghayatan sufisme kembali ditanamkan dalam kalbu kehidupan masyarakat modern untuk merubah keshalihan formala kepada keshalihan sufistik atau nilai-nilai yang terkandung didalam ajaran Islam dalam hal ini tasawuf.

Tasawuf memiliki filosofi yang mendalam tentang spiritualitas dan religiusitas aspek agama, sehingga spiritualitas yang sehat dapat diperoleh dari mistisisme positif, di tengah-tengah ancaman "sakit religiusitas" yang berasal dari otoritarianisme agama. Sufisme penyelamatan menjanjikan. Terutama di tengah-tengah krisis materialis yang serba hidup, hedonis, sekuler, ditambah kehidupan semakin sulit secara ekonomi dan psikologis itu, tasawuf memberikan obat penawar rohani yang memberikan daya tahan.

Semenjak masa al-Ghazali, tasawuf ${ }^{3}$ merupakan salah satu pemikiran Islam yang menghegemoni umat Islam hingga sekarang. Hampir seluruh etika

${ }^{2}$ Ihsan berarti berbuat baik. Orang yang berbuat Ihsan disebut muhsin berarti orang yang berbuat baik.setiap perbuatan yang baik yang nampak pada sikap jiwa dan prilaku yang sesuai atau dilandaskan pada aqidah dan syariat Islam disebit Ihsan. Dengan demikian akhlak dan Ihsan adalah dua pranata yang berada pada suatu sistem yang lebih besar yang disebut akhlaqul karimah. Lihat Wahhab Muhammad bin Abdul, Tiga Prinsip Dasar dalam Islam (Riyadh: Darussalam, 2004), hlm.23-24

${ }^{3}$ Secara etimologis para ahli berselisih tentang asal kata tasawuf. Sebagian menyatakan berasal dari kata "Shuffah" artinya emper masjid Nabawi yang didiami oleh sebagian sahabat 
Islam yang diyakini sekarang, metode dalam mendekatkan diri kepada Allah, kesemuanya merupakan penafsiran dari kaum sufi. Penafsiran mereka telah mengakibatkan umat Islam lebih memperhatikan akhirat ketimbang dunia, dan lebih memperhatikan ritual ibadah ketimbang perjuangan dalam menegakkan keadilan sosial.

Sungguhpun demikian, untuk menjelaskan peranan agama di tengah masyarakat modern yang menjadi salah satu ciri fundamental adalah tumbuhnya "sekularisme", apalagi menjelaskan tanpa harus ada unsur apologi, maka hal demikian itu bukanlah perkara mudah. ${ }^{4}$ Barangkali benar yang dikatakan Azyumardi Azra yang mengatakan ada benarnya dihubungkan dengan agama diluar Islam. Di dalam Islam menurut kesejarahannya, ternyata di dalamnya sejak zaman awal sampai detik ini senantiasa terdapat ijtihad kontinyu tentang apa yang disebut dengan tradisi sufisme. ${ }^{5}$

Era modernisme telah melahirkan kemajuan sains yang sangat menakjubkan. Teknologi tingkat tinggi yang diterapkan hampir dalam kehidupan manusia tidak terlepas dari peran modernitas. ${ }^{6}$ Misal kemudahan transportasi dan akses informasi banyak memberi manfaat kepada manusia. Dalam waktu yang sangat relatif singkat manusia bisa melakukan tour ke berbagai tempat belahan dunia. Perbedaan tempat juga tidak memutus jalinan komunikasi. Dengan demikian, modernisme mempunyai peran vital bagi perjalanan

\footnotetext{
Anshar. Ada pula yang mengatakan berasal dari kata "Shaf' artinya barisan. Seterusnya ada yang mengatakan berasal dari "shafa" artinya bersih/jernih, dan masih ada lagi yang mengatakan berasal dari kata"Shufanah", sebutan nama kayu yang bertahan tumbuh dipadang pasir, terakhir ada yang mengatakan dari bahasa Yunani" theosofi", artinya ilmu ketuhanan. Namum yang terakhir ini tidak disetujui oleh H.A.R. Ghib. Dia cenderung pada kata tasawuf berasal dari "shuf (bulu domba)", dan orang yang berpakaian bulu domba disebut "mutashawwif", perilakunya disebut tasawuf lihat dalam buku karya M. Amin Syukur, Intelektualisme Tasawuf Studi Intelektualisme Tasawuf al-Ghazali (Yogyakarta: Pustaka Pelajar, 2002), hlm. 11-12. Dan Lihat juga H.A.R. Gibb, Islam dalam Lintasan Sejarah (Jakarta: Bharata, 1964), hlm. 112.

${ }^{4}$ Mohammad Damami, Tasawuf Positif dalam Pemikiran Hamka (Yogyakarta: Pustaka Baru, 2000), hlm. 220.

${ }^{5}$ Muhammad Wahyuni Nafis, (ed.), Rekonstruksi dan Renungan Religius Islam (Jakarta: Penerbit Paramadina, 1996), hlm. 288-289.

${ }^{6}$ Nazaruddin Latif \& Nasrullah (ed), Tasawuf Modernitas pencarian Makna Spiritual di Tengah Problematika Sosial (Yogyakarta: Politeia Press, 2008) ,hlm.vi.
} 
peradaban manusia. ${ }^{7}$ Meskipun demikian, dibalik keberhasilan tersebut ternyata modernisme melahirkan problem serius bagi kelangsungan hidup manusia. Modernisme hanya mampu memberi kenikmatan jasmani namun tidak mampu memberi kepuasan ruhani. Setiap hari manusia hanya disuplai materi-materi yang bersifat jasmaniyah yang justru membuat kehidupan manusia menjadi materialistis, hedonis, dan konsumeris. Sementara suplai materi bersifat ruhaniyah diabaiakn begitu saja, sehingga mengakibatkan ketimpangan dalam kehidupan manusia dan menjadi kering makna.

Dunia modern juga telah mengantarkan manusia kepada krisis spiritual. Nasr mengungkapkan bahwa Krisis spiritual ini terjadi sebagai akibat dari pengaruh sekulerisasi yang telah cukup lama menerpa jiwa-jiwa manusia modern. Pengaruh pandangan dunia modern dalam berbagai bentuknyanaturalism, materialism, positivisme. Pengaruh sains yang besar dalam kehidupan modern,dengan sengaja atau tidak, telah menyebarkan pandangan sekuler sampai kelubuk jantung dan hati manusa modern. ${ }^{8}$

Ketimpangan makna ini kemudian melahirkan apa yang disebut dengan krisis spiritual. Sebagai akibatnya adalah keterputusan hubungan manusia dengan Tuhannya. Dampaknya terlihat semakin banyak orang frustasi dalam menjalani hidup. Hidupnya tidak tenang karena kepuasan materi yang diperoleh belum mampu meredakan rasa haus yang sesungguhnya, yaitu rasa haus yang terdapat dalam diri yang paling dalam. ${ }^{9}$

Pemaknaan para sufi terhadap nilai-nilai Islam telah meredupkan semangat revolusioner yang telah ditanamkan oleh Rasulullah Saw. Untuk menghadapi tantangan seperti itu, pemaknaan ulang terhadap pemikiran tasawuf mutlak diperlukan sebagai refleksi dan penyesuaian terhadap tuntutan masa sekarang. Karena itu penulis akan memaparkan pada bagian pembahasan.

\footnotetext{
${ }^{7}$ Nazaruddin Latif \& Nasrullah (ed), Tasawuf Modernitas., hlm.vii.

${ }^{8}$ Mulyadi Kartanegara, Menyelami Lubuk Tasawuf (Jakarta:Erlangga,2006),hlm. 264.

${ }^{9}$ Ibid..hlm. vii.
} 


\section{KEBANGKITAN SUFISME ATAU SPIRITUALITAS ISLAM}

Spiritualitas Islam $^{10}$ sebenarnya berakar pada al-Qur'an, kehidupan Rasulullah, dan kehidupan para sahabat dan generasi penerusnya. Meskipun spirtualitas Islam bermula dari sebuah gerakan protes sebagai reaksi atas kondisi politik, ekonomi, dan sosial, ia dapat segera tumbuh ke dalam jalan hidup intelektual seperti halnya jalan hidup spiritual dan jalan hidup yang bersifat kebatinan. Gerakan ini dinamakan gerakan sufisme. Kata sufisme oleh mereka khusus dipakai untuk mistisisme Islam, dan tindak untuk agama-agama lain. ${ }^{11}$ Namum harus ditekankan bahwa sufisme bukan merupakan madzhab. Sufisme tidak menyajikan keyakinan-keyakinan khusus atau doktrin-doktrin yang terlepas keyakinan dan praktik Islami. Sufisme sebenarnya merupakan sebuah cara untuk menginternalkan praktik dan keyakinan Islam. Sufisme juga tidak mengambil dari gagasan teologi dan filosofi, akan tetapi dari kehidupan para Nabi dan kekasih-Nya (para auliya'). ${ }^{12}$

Sufisme (Tasawuf) sebagai sebuah jalan realisasi spiritual dan pencaaian kesucian dan gnosis merupakan aspek dalam (intrinsik/batiniyah) wahyu islam yang pada dasarnya merupakan jantung dan dimensi batin. ${ }^{13}$ Nama itu muncul pada periode belakangan dan ia mengambil beberapa formulasinya dari doktrindoktrin yang berasal dari tadisi Neoplatonik dan Hermetik. Tapi realitas sufisme, doktrin-doktrin dasar dan metodenya, berakar dari wahyu dan terkait erat dengan ruh (spirit) dan juga bentuk lahiriyah (form) Islam sebagaimana tercantum dalam

${ }^{10}$ Spirualtas Islam juga sering disebut dengan istilah mistisisme/tasawuf, lihat Robbi $\mathrm{H}$. Abror, Tasawuf Sosial: Membeningkan Kehidupan dengan Kesadaran Spiritual (Yogyakarta: Pustaka Baru, 2002), hlm. 3. Adapun penegertian Mysticisme, bahasa Yunani Mysterion, dari mystes (orang yang mencari rahasia-rahasia kenyataan) atau myein (menutup mata sendiri),berasal dari agama-agama miteri Yunani yang para calon pemeluknya diberi nama mystes lhat. Lorens Bagus, Kamus Filsafat (Jakarta: Gramedia, 1996), hlm. 652-653. hlm. 53 .

${ }^{11}$ Harun Nasution, Falsafat dan Mistisisme dalam Islam (Jakarta: Bulan Bintang, 1999),

${ }^{12}$ Mahmoud M. Ayoub, Islam Antara Keyakinan dan Praktik Ritual sebuah refleksi Cendekiawan Muslim untuk Kesadaran dan Kesatuan Umat (Yogyakarta: AK Group, 2004), hlm.182-183.

${ }^{13}$ Lihat Budhi Munawar-Rahman, Islam Pluralis, Wacana Kesetaraan Kaum Beriman (Jakarta: Paramadina, tt.) hlm. 175-176. 
al-Qur'an. Ia merupakan perwujudan palaing nyata dan paling konkrit. Bagi orang yang melibatkan diri dalam sufisme, yang menjalani kehidupannya sebagai "pengikut jalan spiritual, sufi yang paling awal dan paling sempurna adalah Nabi Muhammad Saw dan wakil sejati esoterisme Islam adalah Ali bin Abi Thalib. ${ }^{14}$

Simuh, tasawuf sebagai suatu ilmu yang telah berkembang semenjak pertengahan abad kedua hijriyah hingga dewasa ini tentu mengembangkan terminologi atau bahasa khusus yang hanya bisa dimengerti dalam kaitannya dengan ajaran dan penghayatan para sufi. Misalnya istilah "syariat" bagi para sufi pengertiannya selalu dihubungkan dengan istilah hakikat. Maka menurut kacamata para sufi syariat hanya diberi makna sebatas tingkah laku lahiriyah menurut aturan-aturan formal daripada agama. Jadi, laku batin seperti kekhusukan jiwa dalam ibadah dan rasa dekat dengan Tuhan dalam shalat beserta etika itu tidak dimasukkan dalam istilah syariat. Syariat dalam pengertian para sufi tidak termasuk laku batin. ${ }^{15}$

M. Amin Abdullah mengatakan, di dalam Islam terkandung ajaran yang tidak hanya menyangkut lahiriyah saja, akan tetapi juga menyangkut tentang spiritualitas. Ada tiga konsep ajaran Islam yakni Iman, Islam dan Ihsan. Ketiga aspek itu tercampur menjadi satu dan menjadi kesatuan secara utuh dalam tindakan ibadah kepada Allah dan hubungan dengan manusia. Pola-pola hubungan dengan Allah ini di antaranya dengan melakukan shalat dan puasa di samping yang lain, dan ini merupakan metode yang sebenarnya sarat dengan muatan nilai spiritualitas. ${ }^{16}$ Sebenarnya tujuan spiritualitas yang dilakukan seorang adalah bertujuan untuk mendekatkan diri kepada penciptanya. Sebagai orang yang beriman tentunya akan meyakini janji yang dikabarkan oleh Allah bahwa Dia akan memuliakan kedudukan hamba-Nya yang beriman dan

${ }^{14}$ Seyyed Hossein Nasr, Tiga Madhab Utama Filsafat Islam, (Yogyakarta: IRCiSoD, 2006) hlm.145-146.

${ }^{15}$ Simuh, Tasawuf dan Perkembangannya dalam Islam, (Yogyakarta: IRCiSoD, 2019), hlm. 12-13.

${ }^{16}$ M. Amin Abdullah, Studi Agama: Normativitas atau Historisitas (Yogyakarta: Pustaka Pelajar, 2004), hlm. 149. 
bertaqwa. Begitupun Allah yang telah menjajikan kepada orang yang beriman yang menolong agama Allah maka Allah akan meneguhkan kedudukan-Nya.

Maka sesungguhnya kebangkitan sufisme atau spiritualitas Islam sebagai pergerakan terorganisir yang terpisah dari kewajiban individu muslim merupakan salah satu dari akibat penaklukan secara cepat. Orang Islam seringkali lupa bahwa tujuan utama hidup adalah untuk beribadah kepada Allah, tetapi sebagian malah mengejar kekayaan, kekuasaan dan kedudukan yang tersedia di negeri-negeri Islam. ${ }^{17}$

Sedangkan berkaitan degan moral hamba dengan dirinya sendiri itu melahirkan tindakan positif bagi diri pribadi, seperti menjaga kesehatan jiwa dan raga, menjaga fitrah dan memenuhi kebutuhan-kebutuhan roh dan jasmani. ${ }^{18}$ Dengan demikian, krisis spiritual tidak akan terjadi padanya. Dan adapun moral yang terjalin dalam hubungan antara seorang dengan orang lain, menyebutkan keharmonisan, kedamaian dan keselarasan dalam hidup yang dapat mencegah, mengobati berbagai krisis (spiritual, moral, dan budaya). ${ }^{19}$

\section{TASAWUF SEBAGAI PERWUJUDAN IHSAN}

Sebagaimana dijelaskan dalam hadits Nabi Muhammad Saw (Muslim I, tt.) bahwa ihsan adalah merupakan penghayatan seseorang terhadap agamanya. Dengan demikian tasawuf sebagaimana "mistisisme" pada umumnya, bertujuan membangun dorongan-dorongan terdalam manusia, yaitu dorongan untuk merealisasikan diri secara menyeluruh sebagai makhluk yang secara hakiki adalah bersifat keruhanian dan kekal. Lebih dari sekedar esoteris, ganjil dan hayali, ia justru sublim, universal dan benar-benar praktis. ${ }^{20}$

${ }^{17}$ Ibid.,hlm. 179

${ }^{18}$ Aminudin, Konsep Etika Sufistik Menurut al-Ghazali Studi Terhadap Kitab Minhaj alAbidin, Skripsi pada Fakultas Ushuluddin Studi Agama dan Pemikiran Islam Jurusan Aqidah dan Filsafat 2012, hlm. 71.

${ }^{19}$ Abdul Muhayya, "Peran Tasawuf dalam Menanggulangi Krisis Spritual”, Tasawuf dan Kritis (Yogyakarta: Pustaka Pelajar Bekerjasama dengan IAIN Walisongo Press, 2001), hlm. 23-24.

${ }^{20}$ M. Amin Syukur, Menggugat Tasawuf Sufisme dan Tanggung jawab Sosial Abd 21 (Yogyakarta: Pustaka Pelajar, 1999), hlm. 109. 
Seringkali tasawuf diidentifikasi dengan ihsan, adalah tahapan tertinggi yang harus ditempuh oleh seorang muslim untuk menuju Tuhan. Dengan demikian tasawuf merupakan intisari dari agama Islam. Said Aqil Siradj, pakar tasawuf alumnus Universitas Ummul Qura' Makkah mengatakan:'Tasawuf sebagai sifat hamba kepada Tuhannya, terhadap dirinya sendiri serta terhadap alam semesta. Disini tasawuf berfungsi sebagai jalan bagi kehidupan. Oleh karena itu, tasawuf Islam datang sebagai dinamisator terhadap spiritualitas Islam. $^{21}$

Dalam karya Rosyidi yang berjudul Dakwah Kang Jalal dijelaskan ada tiga dimensi dalam agama Islam yakni syariah, tarikat, dan hakikat. Tiga dimensi tersebut sejajar dengan iman, Islam, dan ihsan. ${ }^{22}$ Sebutan qur'ani yang oleh generasi-generasi muslim belakangan disebut sufisme atau tasawuf adalah ihsan (berbuat kebaikan), suatu kualitas Ilahi dan insane yang banyak disebut dalam al-Qur'an, yang secara khusus menyebutkan bahwa Allah mencintai orang-orang yang mempunyai kualitas ini.

Tasawuf merupakan salah satu aspek (esoteris) Islam, sebagai perwujudan dari ihsan yang berarti kesadaran adanya komunikasi dan dialog langsung seorang hamba dengan tuhan-Nya. Esensi tasawuf sebenarnya telah ada sejak masa kehidupan Rasulullah Saw, namun tasawuf sebagai ilmu keislaman adalah hasil kebudayaan Islam sebagaimana ilmu -ilmu keislaman lainnya seperti fiqih dan ilmu tauhid/ilmu kalam. Pada masa Rasulullah belum dikenal istilah tasawuf, yang dikenal pada waktu itu hanyalah sebutan sahabat Nabi.

Adapun dalil mengenai Ihsan dari hadits adalah potongan hadits Jibril yang sangat terkenal (dan panjang), seperti yang diriwayatkan oleh Umar bin Khattab, ketika nabi ditanya mengenai Ihsan oleh malaikat Jibril dan nabi menjawab:

“...Hendaklah engkau beribadah kepada Alloh seolah-olah engkau melihat-Nya. Tapi jika engkau tidak melihat-Nya, maka sesungguhnya Allah melihatmu.....

\footnotetext{
${ }^{21}$ Rosyidi, Dakwah Sufistik Kang Jalal (Jakarta: Paramadina, 2004), hlm. 13.

${ }^{22}$ Ibid.,hlm.48.
} 
Hadits tersebut menunjukan bahwa untuk melakukan Ihsan, sebagai rumusnya adalah memposisikan diri saat beribadah kepada Allah seakan-akan kita bisa melihat-Nya, atau jika belum bisa memposisikan seperti itu maka posisikanlah bahwa kita selalu dilihat oleh-Nya sehingga akan muncul kesadaran dalam diri untuk tidak melakukan tindakan selain berbuat Ihsan atau berbuat baik.

Jadi, unsur pokok utama dalam tasawuf adalah mensucikan diri dan tujuan akhirnya adalah kebahagiaan (al-saadah) dan keselamatan abadi. Tetapi pada dasarnya tasawuf merupakan implementasi dari ihsan yang berarti beribdah kepada Allah Swt seakan-akan melihat-Nya, apabila tidak mampu yang demikian, maka harus disadari bahwa Allah Swt melihat diri kita, yang demikian itu adalah realitas penghayatan seseorang terhadap agamanya.

\section{KARAKTERISTIK TASAWUF SEBAGAI PENINGKATAN KESADARAN MORAL}

Salah satu karakteristik tasawuf ialah peningkatan moralitas/etika. Oleh karena itu, tasawuf mempunyai kaitan erat dengan teori-teori moral yang lazim yang disebut dengan etika/moralitas. ${ }^{23}$ Misal mari kita perhatikan pada teori etika al-Ghazali pada umumnya ditulis setelah menempuh hidup jalan sufi. Karena itu kondisi kerohaniannya banyak berpengaruh terhadap bangunan konsepsi etikanya. Disisi lain teori etikanya juga dilatar belakangi oleh kondisi obyektif yang dihadapi dalam kehidupan masyarakat yang menurut hasil penelitiannya telah mengalami degredasi moral yang sangat merugikan kehidupan akhirat. Didalam pendahuluannya dalam kitab Ihya Ulum al-Din dan juga dalam al-Munqidz Min al-Dalal ia menggambarkan secara singkat mengenai kondisi moral itu, sebab musabbabnya dan menjelaskan permasalahn pokoknya. $^{24}$

Tasawuf mengupas tata cara menyucikan hati, mendekatkan diri kepada Allah dengan sedekat-dekatnya, dan merasakan kehadiran Allah dalam

\footnotetext{
${ }^{23}$ M. Amin Syukur, Intelektualisme Tasawuf Studi Intelektualisme Tasawuf al-Ghazali (Yogyakarta: Pustaka Pelajar, 2012), hlm. 183.

${ }^{24}$ Ibid.,hlm. 183.
} 
kehidupan sehari-hari guna mewujudkan integritas moral yang tinggi pada pribadi seorang muslim. Kini, tasawuf menjadi fenomena masyarakat modern; bahkan menjadi bagian dari kebutuhan hidup. Masyarakat modern mencari tasawuf untuk melengkapi belahan kehidupannya yang hilang, yakni nilai-nilai spiritualitas.

Sayyed Hossein Nasr memandang manusia modern mengalami dekadensi humanistik karena mereka telah kehilangan pengetahuan langsung mengenai dirinya. Pengetahuan ini bersifat dangkal, karena diperoleh dari pinggir lingkaran eksistensi manusia, yakni kesadaran tentang ketuhanan dan merasakan kehadiran-Nya dalam kehidupan. Manusia modern bagaikan berkasberkas cahaya yang tenggelam dan gelap, tidak sanggup menghubungkan dirinya dengan sumber cahaya, yakni Dzat Yang Maha Agung Allah SWT.

Pada dasarnya fitrah setiap manusia dia mengenali Tuhan, walaupun adakalanya penyembahan terhadap Tuhan terjadi tanpa disadari, yaitu ketika manusia melakukan perbuatan akhlaqi, padahal secara sadar dia tidak meyakini adanya Tuhan penyembahan melalui alam sadar memang hanya bisa dilakukan oleh manusia tertentu, tetapi jenis penyembahan dari bawah sadar dilakukan semua manusia. $^{25}$

Banyak ahli berpendapat bahwa esensi Islam adalah moral, yaitu moral antara seorang hamba dengan Allah, dengan dirinya sendiri, dan dengan orang lain, termasuk dengan anggota masyarakat dan dengan lingkungannya. Moral yang terjalin dalam hubungan antara seorang hamba dengan Allah menegasikan berbagai moral yang buruk, seperti tamak, rakus, gila harta, gila hormat sekalipun, menindas, mengabdikan diri kepada selain Allah (syirik), membiarkan orang yang lemah dan berkhianat.

Jika moralitas yang menjadi esensi dari agama Islam, maka pada diri nabi Muhammad juga pernah bersabda bahwa seorang mukmin yang sempurna imannya adalah yang paling sempurna moralnya. Hadits lain juga menyebutkan

${ }^{25}$ Murtadha Muthahhari, Filsafat Moral; Kritik atas Berbagai Pandangan Moral, terj. M. Babul Ulum dan Edi Hendri M (Jakarta: al-Huda, 2004), hlm. 117. 
bahwa sesungguhnya misi dari kerasulan Muhammad adalah untuk menyempurnakan akhlak yang mulia. Hadits yang pertama menyiratkan bahwa kesempurnaan iman dan moral adalah dua hal yang saling terkait dan menopang, sedangkan hadits yang kedua mengandung arti kesempurnaan misi kerasulan Muhammad tergambarkan dari kesempurnaan moralitas umat. Jika pemaknaan terhadap dua hadits diatas diselaraskan, maka sesungguhya moralitas Islam adalah gambaran dari tingkat keimanan yang telah dicapai oleh umat.

\section{KESIMPULAN}

Dari seluruh paparan diatas, maka dapat diperoleh suatu pemahaman bahwasanya di dalam Islam menurut fakta kesejarahannya, ternyata di dalamnya sejak zaman awal sampai detik ini senantiasa terdapat ijtihad yang berkelanjutan tentang apa yang disebut dengan tradisi sufisme. Sampai kepada pengaktualisasikan didalam kehidupan manusia dewasa ini. Tasawuf juga sering di identikkan dengan ihsan, yang merupakan sebuah tahapan tertinggi yang harus ditempuh oleh seorang muslim untuk menuju Tuhannya.

Dan adapun yang menjadi karakteristik tasawuf ialah peningkatan kesadaran akan pentingnya moralitas/etika. Dari sini penulis menyadari betul apa yang menjadi kegelisahan manusia pada umumnya dalam menjalani kehidupan memang harus balance/penyeimbang antara dunia dan akhirat (yang bersifat duniawi/ukhrawi).

Maka sampai-sampai Sayyed Hossein Nasr memandang manusia modern mengalami dekadensi humanistik karena mereka telah kehilangan pengetahuan langsung mengenai dirinya. Pengetahuan ini bersifat dangkal, karena diperoleh dari pinggir lingkaran eksistensi manusia, yakni kesadaran tentang ketuhanan dan merasakan kehadiran-Nya dalam kehidupan. Manusia modern bagaikan berkas-berkas cahaya yang tenggelam dan gelap, tidak sanggup menghubungkan dirinya dengan sumber cahaya, yakni Dzat Yang Maha Agung Allah SWT.

Maka wajarlah jika seseorang yang kemudian dengan semena-mena tanpa adanya rasa malu dan takut melakukan praktik-praktik seperti korupsi 
kolusi dan nepotime $(\mathrm{KKN})$, itu semua di karenakan gelap matahatinya, tertutup matahatinya jauh dari sumber cahaya tidak bisa terhubung kepada sumber cahaya yatu Allah Tuhan Semeseta Alam.

\section{DAFTAR PUSTAKA}

Abdullah, Amin M. Studi Agama: Normativitas atau Historisitas Yogyakarta: Pustaka Pelajar, 2004.

Abror, Robbi H. Tasawuf Sosial: Membeningkan Kehidupan dengan Kesadaran Spiritual Yogyakarta: Pustaka Baru, 2002.

Alfan, Muhammad. Filsafat Etika Islam Bandung: Pustaka Setia, 2011.

Asmaran, Pengantar Studi Tasawuf, Jakarta: PT. Raja Grafindo Persada, 2012.

Ayoub, Mahmoud M. Islam Antara Keyakinan dan Praktik Ritual sebuah refleksi Cendekiawan Muslim untuk Kesadaran dan Kesatuan Umat Yogyakarta: AK Group, 2004.

Bagus, Lorens. Kamus Filsafat Jakarta: Gramedia, 1996.

Damami, Mohammad. Tasawuf Positif dalam Pemikiran Hamka Yogyakarta: Pustaka Baru, 2000.

Djatnika, Rachmat. Sistem Etika Islami; akhlak mulia Jakarta: Putaka Panjimas, 1996.

Kartanegara, Mulyadi. Menyelami Lubuk Tasawuf Jakarta:Erlangga, 2006.

Latif , Nazaruddin \& Nasrullah (ed). Tasawuf Modernitas pencarian Makna Spiritual di Tengah Problematika Sosial Yogyakarta: Politeia Press, 2008.

Muhayya, Abdul. "Peran Tasawuf dalam Menanggulangi Krisis Spritual", Tasawuf dan Kritis Yogyakarta: Pustaka Pelajar Bekerjasama dengan IAIN Walisongo Press, 2001.

Muthahhari, Murtadha. Filsafat Moral; Kritik atas Berbagai Pandangan Moral, terj. M. Babul Ulum dan Edi Hendri M Jakarta: al-Huda, 2004.

Nafis, Muhammad Wahyuni. (ed.), Rekonstruksi dan Renungan Religius Islam Jakarta: Penerbit Paramadina, 1996. 
Nasr, Seyyed Hossein. Tiga Madhab Utama Filsafat Islam, Yogyakarta: IRCiSoD, 2006.

Nasution, Harun. Falsafat dan Mistisisme dalam Islam Jakarta: Bulan Bintang, 1999.

Rahman, Budhi Munawar-Rahman. Islam Pluralis, Wacana Kesetaraan Kaum Beriman Jakarta: Paramadina, tt.

Rosyidi, Dakwah Sufistik Kang Jalal, Jakarta: Paramadina, 2004.

Simuh, Tasawuf dan Perkembangannya dalam Islam, Yogyakarta: IRCiSoD, 2019.

Syukur, Amin M. Intelektualisme Tasawuf Studi Intelektualisme Tasawuf alGhazali (Yogyakarta: Pustaka Pelajar, 2012.

. Menggugat Tasawuf Sufisme dan Tanggung jawab Sosial Abd 21 Yogyakarta: Pustaka Pelajar, 1999.

Zubair, Achmad Charis. Kuliah Etika Jakarta: Rajawali Press, 1990. 